\title{
Ákvörðun skiptaverðs í skiptiútboði Íbúðalánasjóðs
}

\author{
Hersir Sigurgeirsson ${ }^{1}$
}

\begin{abstract}
Ágrip
Í lok júní árið 2004 bauð Íbúðalánasjóður eigendum hús- og húsnæðisbréfa að skipta peim út fyrir ný skuldabréf, svokölluð íbúðabréf. Deutsche Bank London AG var aðalráðgjafi sjóðsins við skiptiútboðið og ráðlagði sjóðnum meðal annars um ákvörðun skiptaverðsins. Skiptaverð hús- og húsnæðisbréfa í útboðinu átti að ákvarðast af ávöxtunarkröfu peirra á markaði og ávöxtunarkrafa íbúðabréfanna átti að ákvarðast af ávöxtunarkröfu húsnæðisbréfa með sérstöku frádragi pannig að skiptaverð peirra væri hærra en húsnæðisbréfanna. Skiptaverðið í útboðinu var ekki í samræmi við pessar fyrirætlanir Íbúðalánasjóðs; verð húsbréfanna var of hátt og íbúðabréfanna of lágt. Sjóðurinn keypti pví útistandandi bréf á of háu verði og seldi nýju skuldabréfin á of lágu verði.

Með pví að endurskapa skiptaverðið sem Íbúðalánasjóður bauð í útboðinu eru færð rök fyrir pví að sjóðurinn eða ráðgjafar hans hafi gert mistök við ákvörðun sína sem fólust í fjórum villum. Prjár peirra höfðu lítil sem engin áhrif á endanleg skiptihlutföll í útboðinu en ein peirra hafði talsverð áhrif og kostaði sjóðinn um 1,5 milljarða kr. á verðlagi ársins 2004. Sú villa fólst í pví að bera saman ávöxtunarkröfu tveggja skuldabréfa sem reiknuð var miðað við mismunandi vaxtaform; ávöxtunarkrafa húsnæðisbréfa var reiknuð miðað við árlega vaxtavexti en ávöxtunarkrafa íbúðabréfa miðað við hálfsárslega vaxtavexti. Mistökin má hugsanlega rekja til pess að mismunandi venjur eru varðandi framsetningu ávöxtunarkröfu skuldabréfa á íslenskum skuldabréfamarkaði annars vegar og sumum evrópskum mörkuðum hins vegar.
\end{abstract}

\section{Abstract}

At the end of June 2004 the Icelandic Housing Financing Fund (HFF) offered owners of Housing Bonds (HB) and Housing Authority Bonds (HAB), issued by the fund, to exchange

${ }^{1}$ Höfundur er dósent í fjármálum við Viðskiptafræðideild Háskóla Íslands. Hann lauk B.Sc. prófi í stærðfræði frá Háskóla Íslands árið 1995, M.Sc. prófi í fjármálastærðfræði frá Stanford University árið 2000 og Ph.D. gráðu í hagnýtri stærðfræði frá sama skóla árið 2001. Á árunum 2003-2006 starfaði hann sem verðbréfasali hjá Kauppingi (síðar KB banka) og hafði m.a. með höndum eigin viðskipti bankans með íslensk skuldabréf, par á meðal skuldabréf útgefin af Íbúðalánasjóði. Hann hafði umsjón með pátttöku Kauppings í skiptiútboði Íbúðalánasjóðs í júní 2004 og uppgötvaði mistökin, sem fjallað er um í greininni, pegar tilkynnt var um skiptaverð í útboðinu. Hann benti starfsmönnum sjóðsins á mistökin áður en útboðið fór fram. Höfundur veitti Rannsóknarnefnd Alpingis um Íbúðalánasjóð o.fl. ráđgjöf frá maí 2012 til júní 2013. Hann benti rannsóknarnefndinni á mistökin í skiptiútboðinu í júlí 2012. 
them for new bonds, called HFF Notes. Deutsche Bank London AG acted as advisor and lead manager for the exchange offer and assisted the fund in determining the exchange prices. The exchange price of the HBs and HABs was to be determined from their market yield and the yield of the HFF Notes was to be determined from the yield of the HABs by subtracting a specified spread. The announced exchange prices were not in accordance with these intentions; the prices of the HBs were too high and the prices of the HFF Notes too low. HFF therefore paid too much for the outstanding bonds and sold the new bonds at too low prices.

By recreating the exchange prices offered in the exchange offer it is argued that the fund or its advisors made four errors in the determination of the prices. Three of them had little or no effect on the exchange ratios, but one of them had a significant effect and cost the fund 1.5 billion $\mathrm{kr}$. The error involved comparing the yields of two bonds based on different compounding frequencies; the yield on the older HAB bonds was based on annual compounding whereas the yield on the new HFF Notes was based on semi-annual compounding. The error can possibly be traced to different conventions regarding bond yields in the Icelandic bond market and some European markets.

JEL flokkun: D44, G12, G24

Lykilorð: skuldabréf, vaxtavextir, ávöxtunarkrafa

\section{Inngangur}

Í lok júní árið 2004 bauð Íbúðalánasjóður eigendum húsbréfa og húsnæðisbréfa að skipta peim út fyrir ný skuldabréf, svokölluð íbúðabréf, í sérstöku skiptiútboði. Sjóðurinn hafði áður fengið Deutsche Bank London AG sér til ráðgjafar við útboðið. Hlutverk ráðgjafanna var meðal annars að aðstoða sjóðinn við að ákvarða skiptaverðið í útboðinu. Ein af niðurstöðum Rannsóknarnefndar Alpingis um Íbúðalánasjóð o.fl. (hér eftir „rannsóknarnefndin“) var að í útboðinu hefði verið gerð ákveðin reiknivilla við ákvörðun skiptaverðsins og var tjón Íbúðalánsjóðs vegna reiknivillunnar metið 1,5 milljarðar kr. á verðlagi ársins 2004 (Sigurður Hallur Stefánsson, Kirstín P. Flygenring og Jón Porvaldur Heiðarsson, 2013, 3. bindi bls. 171).

Rannsóknarnefndin skilaði skýrslu sinni hinn 2. júlí 2013 og í kjölfarið fjallaði Stjórnskipunar- og eftirlitsnefnd Alpingis (hér eftir „,nefndin“) um skýrsluna. Nefndin skilaði áliti sínu hinn 24. mars 2014 og skiptist pað í tvo hluta, meiri hluta og minni hluta. Hvorki meiri hlutinn né minni hlutinn taldi að sannað væri að mistök hefðu verið gerð við útreikning skiptaverðsins. Í áliti meiri hlutans segir: „Sannfærandi upplýsingar hafa komið fram um að mistök hafi ekki verið gerð við útreikning álagsins og áréttar meiri hlutinn að rannsóknarnefndin aflaði ekki fullnægjandi upplýsinga til að leggja mat á petta atriði.“ (Stjórnskipunar- og eftirlitsnefnd, 2014). Í áliti minni hlutans segir: „Minni hlutinn tekur ekki afstöðu til meintrar reiknivillu við ákvörðun skiptiálagsins sem hafi kostað 1,5 milljarða kr. (núvirði 3,5 milljarðar kr.) en par virðist standa orð á móti orði rannsóknarnefndarinnar og fyrrverandi stjórnenda Íbúðalánasjóðs og Deutsche Bank." (Stjórnskipunar- og eftirlitsnefnd, 2014). Rökstuðningur nefndarinnar er pví annars vegar sá að rannsóknarnefndin hafi ekki aflað fullnægjandi upplýsinga til að leggja mat á petta atriði og hins vegar sá að fyrrverandi stjórnendur Íbúðalánasjóðs og Deutsche Bank hafi komið fram með sannfærandi rök fyrir pví að ekki hafi verið rangt reiknað. Nefndin tilgreinir pó ekki hver pau rök eru. prátt fyrir afdráttarlausa niðurstöðu 
rannsóknarnefndarinnar um petta atriði virðist pví enn leika vafi á pví hvort mistök voru gerð við útreikning skiptaverðsins í útboðinu. ${ }^{2}$

Í pessari grein er farið rækilega yfir ætlaða aðferðafræði Íbúðalánasjóðs við útreikning á skiptaverðinu og skiptaverðið reiknað miðað við pá aðferðafræði. Niðurstaðan er að mistök voru gerð við útreikninginn; skiptaverð húsbréfanna, bréfanna sem Íbúðalánasjóður keypti, var of hátt, en skiptaverð íbúðabréfanna, bréfanna sem sjóðurinn seldi, var of lágt. Færð eru rök fyrir pví að mistökin hafi falist í fjórum villum sem gerðar voru við útreikning skiptaverðsins og er farið yfir hverja peirra, áhrif hennar á skiptaverðið rakin og tjón sjóðsins vegna hennar metið. Ein villan var minniháttar og hafði lítil sem engin áhrif á útboðið. Tvær peirra voru alvarlegri en reyndust ekki hafa mikil áhrif á útboðið. Fjórða villan hins vegar, sú sem rannsóknarnefndin fjallar um í skýrslu sinni, olli sjóðnum verulegu tjóni en hún fólst í pví að borin var saman ávöxtunarkrafa skuldabréfa sem reiknuð var miðað við mismunandi vaxtaform; ávöxtunarkrafa húsnæðisbréfanna var reiknuð miðað við árlega vaxtavexti en ávöxtunarkrafa íbúðabréfanna miðað við hálfsárslega vaxtavexti. Tjón sjóðsins vegna villunnar er metið tæplega 1,5 milljarðar kr. Að lokum er bent á að hugsanleg skýring á pessari villu sé að mismunandi venjur eru varðandi framsetningu ávöxtunarkröfu á skuldabréfamörkuðum.

Til að auðvelda lesandanum að sannreyna alla útreikninga og niðurstöður eru allar forsendur útreikninga, útreikningarnir sjálfir og niðurstöður peirra sett fram í premur töflum í viðauka.

\section{Skiptiútboð Íbúðalánasjóðs og skiptaverðið}

\subsection{Breytingar á fyrirkomulagi fjármögnunar Íbúðalánasjóðs}

Pegar Íbúðalánasjóður var stofnaður árið 1999 voru útlán hans fjármögnuð með útgáfu tveggja tegunda skuldabréfa, svokallaðra húsbréfa annars vegar og húsnæðisbréfa hins vegar. Húsbréfin voru með útdráttarfyrirkomulagi og voru uppgreiðanleg af hálfu Íbúðalánasjóðs til jafns við uppgreiðslur útlána sjóðsins en húsnæðisbréfin voru óuppgreiðanleg, sjá töflu 1. Í mars árið 2001 skipaði fjármálaráðherra nefnd um endurskipulagningu á útgáfumálum Íbúðalánasjóðs. Nefndin skilaði niðurstöðum sínum í október árið 2003 og var helsta niðurstaða hennar að sjóðurinn skyldi gefa út eina gerð skuldabréfa í stað tveggja, svokölluð íbúðabréf, sem ekki skyldu vera uppgreiðanleg (Bergpóra Bergsdóttir, Ingi Valur Jóhannsson, Sigurður Geirsson, Tómas Örn Kristinsson og Pórður Jónasson, 2003). Í töflu 1 eru sýndir helstu skilmálar pessara priggja tegunda skuldabréfa Íbúðalánasjóðs. Frekari skilmála einstakra flokka skuldabréfanna má sjá í töflu 12 í viðauka.

\footnotetext{
${ }^{2}$ Rétt er að benda á að bæði meiri hlutinn og minni hlutinn fjalla um reiknivillu í útreikningi eða ákvörðun skiptiálagsins en niðurstaða rannsóknarnefndarinnar var að reiknivilla væri í útreikningi skiptaverðsins, sem er ekki alveg pað sama. Hins vegar hefur pessi ranga orðanotkun engin efnisleg áhrif á niðurstöðu nefndarinnar.
} 
Tafla 1. Helstu skilmálar skuldabréfa Íbúðalánasjóðs.

Frekari skilmála einstakra flokka má sjá í töflu 12 í viðauka. Heimild: Íbúðalánasjóður (2004c)

\begin{tabular}{l|cccc}
\hline Auðkenni-Heiti & Ákvæðisvextir & $\begin{array}{c}\text { Fjöldi } \\
\text { afborgana }\end{array}$ & Uppgreiðanleg? & $\begin{array}{c}\text { Tegund } \\
\text { afborgana }\end{array}$ \\
\hline IBH - Húsbréf & $4,75 \%$ & 4 á ári & Já & Útdráttur \\
IBN - Húsnæðisbréf & $2,70 \%$ & 1 á ári & Nei & Jafngreiðslur \\
HFF - Íbúðabréf & $3,75 \%$ & 2 á ári & Nei & Jafngreiðslur \\
\hline
\end{tabular}

Helstu tillögur nefndarinnar urðu að lögum³ hinn 27. maí 2004 (Lög um breytingu á lögum um húsnæðismál nr. 57/2004). Með lögunum fékk Íbúðalánasjóður jafnframt heimild til að bjóða eigendum húsbréfa og húsnæðisbréfa að skipta peim út fyrir hin nýju íbúðabréf. Hinn 11. júní tilkynnti sjóðurinn að eigendum valinna flokka húsbréfa og húsnæðisbréfa yrði boðið að skipta peim út fyrir ný skuldabréf og 21. júní auglýsti sjóðurinn að skiptiútboðið yrði haldið dagana 28. - 30. júní, birti bráðabirgðar útboðsgögn og aðferðafræðina sem beitt yrði við ákvörðun skiptaverðsins og upplýsti að tilkynnt yrði um endanlegt skiptaverð hinn 28. júní. Endanlegt skiptaverð var birt í fréttakerfi Kauphallar að morgni hins 28. júní. Hinn 2. júlí tilkynnti Íbúðalánasjóður um niðurstöður skiptiútboðsins; ný íbúðabréf að nafnverði um 338 milljarðar kr. voru gefin út og skipt út fyrir útistandandi hús- og húsnæðisbréf (Íbúðalánasjóður, 2004a, 2004b, 2004d, 2004e, 2004f).

\subsection{Skiptaverðið í útboðinu}

Í tilkynningu Íbúðalánasjóðs hinn 28. júní var skiptaverðið gefið í tveimur töflum eins og sýnt er hér í töflum 2 og 3 (Íbúðalánasjóður, 2004e).

Tafla 2. Kaupverð útistandandi hús- og húsnæðisbréfa í skiptiútboðinu. Heimild: Íbúðalánasjóður (2004e)

\begin{tabular}{l|crr}
\hline Flokkur & Skiptiálag & Kaupverð & Skiptihlutfall \\
\hline IBN 20 & $0 \mathrm{bp}$ & 97,672 & 0,9828098 \\
IBH 21 & $21 \mathrm{bp}$ & 207,949 & 2,0924627 \\
IBH 22 & $21 \mathrm{bp}$ & 183,275 & 1,8441842 \\
IBH 26 & $21 \mathrm{bp}$ & 142,281 & 1,4316857 \\
IBH 37 & $22 \mathrm{bp}$ & 189,495 & 1,9228593 \\
IBN 38 & $0 \mathrm{bp}$ & 105,487 & 1,0704067 \\
IBH 41 & $24 \mathrm{bp}$ & 146,681 & 1,4939840 \\
\hline
\end{tabular}

${ }^{3}$ Eitt viðamikið frávik frá tillögum nefndarinnar varð pó á frumvarpinu í meðförum Alpingis: Til mótvægis við pað að hin nýju íbúðabréf áttu ekki að vera uppgreiðanleg lagði nefndin til að sérstakt uppgreiðslugjald yrði á útlánum sjóðsins sem gerði sjóðinn skaðlausan af uppgreiðslum útlána. Petta ákvæði var í frumvarpinu en var fellt út í meðförum Alpingis. Pótt petta frávik hafi haft mikil áhrif á starfsemi Íbúðalánsjóðs næstu árin hafði pað ekki bein áhrif á skiptiútboðið og pví er ekki fjallað nánar um pað hér. 
Tafla 3. Söluverð íbúðabréfa í skiptiútboðinu.

Heimild: Íbúðalánasjóður (2004e)

\begin{tabular}{l|cc}
\hline Flokkur & Skiptiálag & Söluverð \\
\hline HFF 24 & $-2 \mathrm{bp}$ & 99,380 \\
HFF 34 & $-2 \mathrm{bp}$ & 98,548 \\
HFF 44 & $-2 \mathrm{bp}$ & 98,181 \\
\hline
\end{tabular}

Auðkenni hvers bréfs, í fyrsta dálki hvorrar töflu, segir annars vegar til um tegund bréfsins - IBN fyrir húsnæðisbréf, IBH fyrir húsbréf og HFF fyrir íbúðabréf - og hins vegar hvaða ár lokagjalddagi pess er. Pannig stendur t.d. auðkennið IBN 20 fyrir húsnæðisbréf með lokagjalddaga árið 2020 og HFF 44 fyrir íbúđabréf með lokagjalddaga árið 2044. Í priðja dálki í fyrri töflunni er tilgreint á hvaða verði Íbúðalánasjóður bauðst til að kaupa útistandandi húsbréf og húsnæðisbréf og í sama dálki í peirri seinni á hvaða verði hann myndi selja hin nýju íbúðabréf í skiptum fyrir hús- og húsnæðisbréfin. Annar dálkurinn í hvorri töflu ber heitið „skiptiálag“ og í raun var verðið í priðja dálki reiknað út frá pessu skiptiálagi en nánar er farið yfir með hvaða hætti pað var gert í kafla 4.

Áður hafði verið tilkynnt um að útistandandi skuldabréfum með gjalddaga árið 2026 og fyrr yrði skipt út fyrir íbúðabréfaflokkinn HFF 24, bréfum með gjalddaga árin 2037 og 2038 fyrir HFF 34 og húsbréfaflokknum IBH 41 fyrir HFF 44 (Íbúðalánasjóður, 2004a).

Ef við tökum sem dæmi húsnæðisbréfin IBN 20 pá bauðst Íbúðalánasjóður til að kaupa pau á verðinu 97,672 í skiptum fyrir íbúðabréfin HFF 24 á verðinu 99,380. Eigandi húsnæðisbréfs sem ákvað að skipta út pví fyrir íbúðabréf fékk pví 97,672 / 99,380 = 0,9828098 krónur af nafnverði íbúðabréfsins fyrir hverja krónu nafnverðs húsnæðisbréfsins. ${ }^{4}$ Petta skiptihlutfall er gefið í síðasta dálknum í töflu 2. Fyrir eina milljón að nafnverði af húsnæðisbréfinu IBN 20 fengust pví kr. 982.810 að nafnverði af íbúðabréfinu HFF 24, p.e. nafnverð húsnæðisbréfsins margfaldað með skiptihlutfallinu.

Af töflum 2 og 3 má sjá að Íbúðalánasjóður er í öllum tilfellum nema einu (IBN 20) að greiða mun hærra verð fyrir útistandandi bréf en hann fær fyrir nýju bréfin; hann afhendir pví hærra nafnverð íbúðabréfa í skiptum fyrir hús- og húsnæðisbréfin. Sú staðreynd ein og sér segir hins vegar lítið sem ekkert um skiptaverðið pví bréfin eru mjög mismunandi að gerð. Öll bréfin eru t.d. verðtryggð og pví hafa gömul bréf, p.e. pau sem langt er síðan voru gefin út, miklar áfallnar verðbætur á höfuðstól og eru pví dýrari. Pá voru húsbréfin með útdráttarfyrirkomulagi og vextir af peim voru ekki greiddir fyrr en pau voru dregin út og pví höfðu safnast miklir áfallnir vextir á pau að auki. Pess vegna er til dæmis verð húsbréfanna mjög hátt. Aðrir skilmálar skuldabréfanna voru einnig mismunandi sem hafði áhrif á verð peirra. Skilmála allra skuldabréfanna má sjá í töflu 12 í viðauka.

Til að bera saman verð skuldabréfanna parf að byrja á að breyta verðinu í ávöxtunarkröfu. Peir sem eiga viðskipti með skuldabréf byrja alltaf á að reikna út ávöxtunarkröfu bréfsins út frá verðinu pví verðið eitt og sér segir nánast ekkert um hvort bréfið sé hátt eða lágt verðlagt; ávöxtunarkrafa skuldabréfs er hinn eiginlegi mælikvarði á verð pess. Ákvörðun Íbúðalánasjóðs um verðið í töflum 2 og 3 byggðist líka á pví að ákvarða fyrst ávöxtunarkröfu

${ }^{4}$ Hlutfall skiptaverðanna eins og pau voru tilkynnt er í raun 97,672 / 99,380=0,9828134 en ekki 0,9828098 eins og skiptihlutfallið er tilgreint í tilkynningunni. Mismuninn má líklega rekja til pess að í raun var skiptaverðið reiknað með fleiri aukastöfum en premur. 
bréfanna og reikna svo skiptaverðið út frá peim. Áður en lengra er haldið er pví rétt að fara yfir hvernig verð skuldabréfs er reiknað út frá ávöxtunarkröfu pess og öfugt.

\section{3 Ávöxtunarkrafa skuldabréfs}

Ávöxtunarkrafa skuldabréfs er skilgreind sem peir vextir sem gera núvirði greiðsluflæðis skuldabréfsins jafnt verði pess. P.e. ef verð skuldabréfs er $P$ og greiðsluflæði pess er $\left\{\left(t_{i}, C_{i}\right)\right\}_{i=1}^{N}$, par sem $t_{i}$ táknar tímasetningu (í árum) og $C_{i}$ fjárhæð greiðslu númer $i$ og $N$ táknar heildarfjölda greiðslna, pá er ávöxtunarkrafan $y$ peir vextir sem gefa verðið $P$ pegar greiðsluflæðið er núvirt með peim. Pegar um er að ræða verðtryggt bréf breytast allar greiðslur af bréfinu í takt við breytingar á vísitölu neysluverðs og pví parf að margfalda niðurstöðuna með verðbótapætti, sem er hækkun vísitölunnar frá útgáfu bréfsins. Ef grunnvísitala bréfsins, p.e. vísitala neysluverðs við útgáfu bréfsins, er $I_{0}$ og vísitalan pegar verðið er reiknað er $I_{t}$ pá er verðbótapátturinn $I_{t} / I_{0}$. Verðið er pví:

$$
P=\frac{I_{t}}{I_{0}} \sum_{i=1}^{N} \frac{C_{i}}{(1+y)^{t_{i}}} .
$$

Til að reikna verð skuldabréfs út frá ávöxtunarkröfu parf pví aðeins að stinga greiðsluflæðinu $\left\{\left(t_{i}, C_{i}\right)\right\}_{i=1}^{N}$, verðbótapættinum $I_{t} / I_{0}$ og ávöxtunarkröfunni $y$ inn í jöfnu (1).

Pegar um er að ræða verðtryggð skuldabréf er ávöxtunarkrafan í jöfnu (1) oft kölluð raunávöxtunarkrafa til aðgreiningar frá ávöxtunarkröfu óverðtryggðra bréfa. Par sem öll skuldabréfin sem hér er fjallað um eru verðtryggð er hún hér til einföldunar kölluð ávöxtunarkrafa.

\subsection{Jafngreiðslubréf}

Útreikningur á verði skuldabréfs út frá ávöxtunarkröfu skv. jöfnu (1) er í grundvallaratriðum mjög einfaldur, en par sem skuldabréfin í skiptiútboðinu báru allt að 147 greiðslur pá getur hann verið viðamikill pví summan í jöfnunni inniheldur pá allt að $N=147$ liði. Hins vegar einfaldar pað málið verulega að öll skuldabréfin í útboðinu voru jafngreiðslubréf með reglulegum greiðslum, einni, tveimur eða fjórum á ári, og pví er fjárhæð allra greiðslna tiltekins skuldabréfaflokks sú sama (að raunvirði), $C_{i}=C$. Í pví tilviki er summan í jöfnu (1) sk. jafnhlutfalla- eða kvótasumma og má reikna hana með einföldum hætti. Niðurstaðan er stæða með aðeins einum lið sem mjög einfalt er að reikna:

$$
P=\frac{I_{t}}{I_{0}} \cdot \frac{C}{(1+y)^{t_{1}}} \cdot \frac{1-(1+y)^{-N / m}}{1-(1+y)^{-1 / m}} .
$$

Til að reikna verð jafngreiðslubréfs frá ávöxtunarkröfu parf pví aðeins að stinga inn ávöxtunarkröfunni $y$, verðbótapættinum $I_{t} / I_{0}$, tíma að næstu greiðslu $t_{1}$, fjárhæð hverrar greiðslu $C$, fjölda greiðslna sem eftir eru $N$, og fjölda greiðslna á ári $m$, inn í ofangreinda jöfnu. Fyrir húsnæðisbréfin er $m=1$, fyrir íbúðabréfin er $m=2$ og fyrir húsbréfin er $m=4$.

Húsnæðisbréfin og íbúðabréfin eru hefðbundin jafngreiðslubréf og fjárhæð hverrar jafngreiðslu má ákvarða fyrir pau með eftirfarandi jöfnu:

$$
C=\frac{r / m}{1-(1+r / m)^{-M}}
$$


par sem $r$ eru ákvæðisvextir ${ }^{5}$ skuldabréfsins (sem eru 2,7\% fyrir húsnæðisbréfin og 3,75\% fyrir íbúðabréfin), $m$ er fjöldi greiðslna á ári og $M$ er heildarfjöldi greiðslna frá útgáfudegi bréfsins til gjalddaga pess.

\subsection{Húsbréf}

Húsbréfin eru frábrugðin húsnæðisbréfunum og íbúðabréfunum að pví leyti að pau eru með útdráttarfyrirkomulagi. Fjórum sinnum á ári er tiltekinn höfuðstóll bréfanna dreginn út og endurgreiðist hann að fullu ásamt öllum áföllnum vöxtum og verðbótum frá fyrsta vaxtadegi. Fjárhæð útdráttarins er stillt pannig að pað er eins og um jafngreiðslubréf sé að ræða, en pó með peirri undantekningu að vextir eru reiknaðir miðað við árlega vaxtavexti en ekki fjórum sinnum á ári eins og ef um hefðbundið jafngreiðslubréf með fjórum árlegum afborgunum væri að ræða. Ekki er pví hægt að nota jöfnu (3) óbreytta fyrir fjárhæð hverrar greiðslu par sem hún gerir ráð fyrir að vextir séu reiknaðir fjórum sinnum á ári (með $m=4)$. Til að nota jöfnu (3) parf pví fyrst að breyta ákvæðisvöxtum bréfsins pannig að peir séu sambærilegir pví að vextir séu reiknaðir fjórum sinnum á ári.

Til að breyta jöfnu (3) svo að hún sé rétt fyrir húsbréf táknum við ákvæðisvexti húsbréfanna með $i$ og með $r$ táknum við pá vaxtaprósentu sem gefur sömu árlegu vexti og $i$ ef vextir eru reiknaðir $m$ sinnum á ári. Vaxtaprósentan $r$ er pví stærðin sem stinga má inn í jöfnu (3). Par sem $r$ gefur sömu árlegu vexti $i$ ef vextir eru reiknaðir $m$ sinnum á ári pá er

$$
1+i=(1+r / m)^{m}
$$

Með pví að leysa fyrir $r / m$ fáum við

$$
r / m=(1+i)^{1 / m}-1 .
$$

Með pví að stinga pessu inn í stað $r / m$ í jöfnu (3) fáum við jöfnu fyrir hverja greiðslu af húsbréfi:

$$
C=\frac{(1+i)^{1 / m}-1}{1-(1+i)^{-M / m}}
$$

Allar greiðslur af húsbréfum eru jafnháar að raunvirði og pví má reikna pessa fjárhæð út í eitt skipti fyrir öll í upphafi. Hún miðast pá við upphaflegan höfuðstól húsbréfsins. Hins vegar er pað pannig að eftirstöðvar höfuðstóls húsbréfsins taka breytingum við hverja afborgun. Annars vegar lækka pær við hverja greiðslu um sem nemur peim höfuðstól sem dreginn er út ásamt áföllnum vöxtum og hins vegar hækka pær vegna hærri áfallinna vaxta á pann höfuðstól sem eftir er. Til að ákvarða fjárhæð hverrar greiðslu án pess að purfa að ákvarða upphaflegan höfuðstól bréfsins nægir að átta sig á pví að jafna (6) gildir á hverjum tíma um eftirstöðvar höfuðstóls ef í stað heildarfjölda greiðslna, $M$, er settur fjöldi peirra greiðslna sem eftir eru, $N$. Eftirstöðvar höfuðstóls ásamt áföllnum vöxtum eru á hverjum tíma $(1+i)^{t}$ par sem $i$ eru ákvæðisvextir bréfsins (sem eru 4,75\% fyrir öll húsbréfin sem hér er fjallað um) og $t$ er tíminn í árum frá fyrsta vaxtadegi bréfsins að síðasta gjalddaga. Jöfnu (6) parf pví aðeins að margfalda með eftirstöðvum höfuðstóls og skipta út $M$ fyrir $N$ og pví er jafnan fyrir fjárhæð hverrar greiðslu af húsbréfum:

\footnotetext{
${ }^{5}$ Pað sem hér eru kallaðir ákvæðisvextir eru í daglegu tali yfirleitt kallaðir nafnvextir. Hins vegar er orðið nafnvextir oft einnig notað yfir vexti án tillits til verðbólgu og pá eru vextir að teknu tilliti til verðbólgu kallaðir raunvextir. Par sem öll skuldabréfin sem hér eru til umfjöllunar eru verðtryggð eru ákvæðisvextir skuldabréfanna í raun alltaf raunvextir. Til að forðast misskilning eru peir ekki kallaðir nafnvextir hér.
} 


$$
C=(1+i)^{t} \frac{(1+i)^{1 / m}-1}{1-(1+i)^{-N / m}}
$$

Aðilar á íslenskum skuldabréfamarkaði hafa yfirleitt notað aðra jöfnu til að reikna verð húsbréfa út frá ávöxtunarkröfu, sjá t.d. bls. 225 í Sigurður B. Stefánsson (1994) og bls. 395 í Sigurður B. Stefánsson (2003). Sú jafna er nokkuð flóknari en jafna (2) með $C$ reiknað skv. jöfnu (7) en gefur nákvæmlega sama verð, eins og lesandinn getur sannreynt. Ef sú jafna er notuð er hins vegar ekki eins augljóst hvernig heildarfjárhæð hvers útdráttar er reiknuð; við greiningu á mistökum Íbúðalánasjóðs við útreikning skiptaverðsins skiptir sú stærð máli og pví er jafna (2) með $C$ reiknað skv. jöfnu (7) notuð hér. Pá er munurinn á húsbréfum og hefðbundnum jafngreiðslubréfum, eins og húsnæðisbréfum og íbúðabréfum, skýrari ef jafna (2) er notuð.

\section{4 Ákvörðun skiptaverðsins}

Aðferðinni sem Íbúðalánasjóður beitti til að ákvarða um skiptaverðið er lýst á bls. 10-11 í útboðslýsingu íbúðabréfanna, dags. 28. júní 2004 (Íbúðalánasjóður, 2004c). Par segir að skiptaverð hvers skuldabréfaflokks skuli vera pað verð sem er reiknað út frá ávöxtunarkröfu sem er summan af viðmiðunarkröfu og skiptiálagi flokksins. Petta pýðir að skiptaverð hvers flokks átti að reikna út frá ávöxtunarkröfu, eins og farið var yfir í kafla 3, sem var ákvörðuð sem

$$
\text { ávöxtunarkrafa = viðmiðunarkrafa + skiptiálag. }
$$

Skiptiálag hvers flokks kemur fram í dálki 2 í töflum 2 og 3 í kafla 2.2. Viðmiðunarkrafa hvers flokks er hins vegar, skv. lýsingunni, fundin út frá ávöxtunarkröfu húsnæðisbréfanna tveggja með línulegri brúun eftir lokagjalddaga. Pannig myndar ávöxtunarkrafa húsnæðisbréfanna grunn að verðlagningunni og önnur bréf eru verðlögð með tilteknu álagi ofan á pann grunn. Álagið fyrir íbúðabréfin var reyndar neikvætt, eins og sjá má í töflu 3, svo segja má að verðlagning peirra hafi átt að vera með frádragi frá grunninum. Ávöxtunarkrafa húsnæðisbréfanna tveggja, sem mynduðu grunninn, átti svo að ákvarðast af verði peirra á markaði kl. 14:15 föstudaginn 25. júní 2004.

Hér er á eftir verður farið skref fyrir skref í gegnum aðferðafræði Íbúðalánasjóðs við útreikning skiptaverðsins og skiptaverðið reiknað í samræmi við hana. Í töflu 12 í viðauka eru sýnd öll gildin sem stinga parf inn í jöfnur (2), (3) og (7) hér að framan til að sannreyna að samsvörun er milli útreiknaðs verðs og ávöxtunarkröfunnar.

Áður en farið er í smáatriðin í útreikningi skiptaverðsins er pó rétt að rifja upp að öfugt samband er á milli ávöxtunarkröfu skuldabréfs og verðs pess; ef ávöxtunarkrafan hækkar pá lækkar verð bréfsins og öfugt. Af töflu 2 má sjá að Íbúðalánasjóður bauðst til að kaupa húsbréfin á nokkuð hærri kröfu (pví skiptiálagið á pau var 21-24bp hærra) en húsnæðisbréfin, og par með lægra verði. Ástæða pess er að húsbréfin voru uppgreiðanleg og pví síðri bréf fyrir fjárfesta en húsnæðisbréfin vegna uppgreiðsluáhættu. Álagið, og par með lægra kaupverð húsbréfanna, átti að vera til pess að bæta Íbúðalánasjóði pað upp að taka á sig uppgreiðsluáhættuna. Hins vegar ætlaði Íbúðalánasjóður sér að selja nýju íbúðabréfin á lægri kröfu en húsnæðisbréfin, p.e. hærra verði. Pessar tvær tegundir skuldabréfa eru mjög svipaðar, báðar tegundir verðtryggð, óuppgreiðanleg jafngreiðslubréf, og pví hefði verð (p.e. ávöxtunarkrafa) peirra átt að vera svipað. Rökstyðja mátti hærra verð (p.e. lægri kröfu) 
íbúðabréfanna með pví að pau væru betri m.a. af pví að pau væru gefin út í alpjóðlegri uppgjörsmiðstöð og að flokkar peirra væru stærri.

\subsection{Verð viðmiðunarbréfanna}

Samkvæmt lýsingunni (á bls. 10-11 í útboðslýsingu íbúðabréfanna) skyldi byrja á að ákvarða verð húsnæðisbréfanna IBN 20 og IBN 38 og átti ávöxtunarkrafa peirra að vera viðmiðun fyrir önnur bréf í útboðinu. Verð peirra átti að ákvarðast af miðgildi kaup- og sölutilboða í kauphöll kl. 14:15 hinn 25. júní 2004, framreiknað til uppgjörsdags útboðsins hinn 7. júlí miðað við stýrivexti Seðlabanka með eftirfarandi jöfnu:

$$
P=P_{S}\left(1+R \frac{d}{360}\right)
$$

par sem $P_{S}$ er miðgildi kaup- og sölutilboða, $R$ eru stýrivextir Seðlabanka Íslands og $d$ er dagafjöldi frá uppgjörsdegi viðskipta 25. júní til uppgjörsdags skiptiútboðsins.

Stýrivextir Seðlabanka voru $R=6,25 \%$ í lok júní 2004. Viðskipti sem fóru fram föstudaginn 25. júní 2004 voru með uppgjörsdag mánudaginn 28. júní og uppgjörsdagur skiptiútboðsins var 7. júlí; fjöldi daga milli pessara tveggja dagsetninga er $d=9$. Skv. heimasíðu Kauphallarinnar var síðasta viðskiptaverð pann dag 97,4 fyrir IBN 20 og 105,29 fyrir IBN 38 en ekki eru birtar opinberlega upplýsingar um hvert miðgildi kaup- og sölutilboða húsnæðisbréfanna í kauphöll var kl. 14:15 pann dag. Ekki eru pví nægar upplýsingar til staðar til að reikna verð viðmiðunarbréfanna miðað við gefnar forsendur. ${ }^{6}$ Niðurstaða Íbúðalánasjóðs var hins vegar að viðmiðunarverð IBN 20 var 97,672 og viðmiðunarverð IBN 38 var 105,487. Sé pað notað til að reikna til baka miðgildi tilboðanna fæst að miðgildið fyrir IBN 20 var 97,520 og miðgildið fyrir IBN 38 var 105,322, sem er ekki langt frá dagslokaverðunum. Par sem verð í tilboði um skuldabréfaviðskipti í kauphöll er sett fram sem margfeldi af 0,005 er líklegt að miðgildi tilboða í IBN 38 hafi verið 105,3225.

Hér eru pví ekki forsendur til annars en að gera ráð fyrir að verð viðmiðunarbréfanna hafi verið rétt reiknað. Hins vegar er pað svo að pótt pessi verð hefðu ekki verið rétt reiknuð hefði pað haft sáralítil ef einhver áhrif á skiptihlutföllin í útboðinu.

\section{2 Ávöxtunarkrafa viðmiðunarbréfanna}

Pví næst átti ávöxtunarkrafa pessara tveggja bréfa að reiknast út frá verði peirra. Til að reikna ávöxtunarkröfuna með jöfnu (2) parf að reikna út dagvísitölu neysluverðs á uppgjörsdegi viðskiptanna. Á pessum tíma var hún reiknuð með pví að framreikna vísitölu í upphafi mánaðar til uppgjörsdagsins með skammtímaverðbólguspá Seðlabanka Íslands. Vísitala neysluverðs var 235,7 hinn 1. júlí 2004 og skammtímaspá Seðlabanka fyrir 3. ársfjórðung var 4\% á ársgrundvelli (Seðlabanki Íslands, 2004, bls. 23). Dagvísitalan var pví $I_{t}=235,7 \cdot(1+4 \%)^{6 / 360}=235,85412$.

Niðurstaða útreiknings á ávöxtunarkröfunni skv. jöfnu (2) miðað við pessi verð og pessa dagvísitölu er að ávöxtunarkrafa IBN 20 var 4,050\% og ávöxtunarkrafa IBN 38 var 3,947\% (sjá töflu 12 í viðauka með öllum forsendum og útreikningum).

${ }^{6}$ Kauphöllin geymir upplýsingar um tilboð innan dags í gagnagrunni sínum en birtir pær hvergi opinberlega og pað virðist einhverjum vandkvæðum bundið að nálgast pau gögn. Par sem pað hefur sáralítil ef einhver áhrif á niðurstöður greinarinnar hvort verðin hafi verið pau sem hér er ályktað eða ekki pá var ekki lagt í frekari vinnu til að nálgast pessi gögn. 


\subsection{Viðmiðunarkrafa hvers skuldabréfaflokks}

Næsta skref var að reikna viðmiðunarkröfu fyrir hvern flokk skuldabréfa. Samkvæmt lýsingunni skyldi pað gert með línulegri brúun á ávöxtunarkröfu húsnæðisbréfanna eftir lokagjalddaga hvers flokks, skv. formúlunni

$$
y_{k}=y_{20}+\left(y_{38}-y_{20}\right) \frac{d_{k}}{d_{38}}
$$

par sem $y_{20}=4,050 \%$ er viðmiðunarkrafa IBN 20, $y_{38}=3,947 \%$ er viðmiðunarkrafa IBN 38, $d_{k}$ er fjöldi daga milli lokagjalddaga IBN 20 og skuldabréfaflokksins sem verið er að ákvarða kröfuna fyrir og $d_{38}=6.575$ er fjöldi daga milli lokagjalddaga IBN 20 og IBN 38. Í töflu 4 má sjá útreikninga á viðmiðunarkröfu fyrir hvern flokk skuldabréfa skv. jöfnu (9).

Tafla 4. Viðmiðunarkrafa hvers skuldabréfaflokks reiknuð skv. aðferðafræði Íbúðalánasjóðs.

\begin{tabular}{l|rrr}
\multicolumn{2}{c}{ Heimild: Íbúðalánasjóður (2004c) og eigin útreikningar. } \\
\hline Flokkur & $\begin{array}{c}\text { Loka- } \\
\text { gjalddagi }\end{array}$ & \multicolumn{1}{c}{$\boldsymbol{d}_{\boldsymbol{k}}$} & $\begin{array}{c}\text { Viðmiðunar- } \\
\text { krafa }\left(\boldsymbol{y}_{\boldsymbol{k}}\right)\end{array}$ \\
\hline IBN 20 & 1.1 .2020 & 0 & $4,050 \%$ \\
IBN 38 & 1.1 .2038 & 6.575 & $3,947 \%$ \\
IBH 21 & 15.1 .2021 & 380 & $4,044 \%$ \\
IBH 22 & 15.12 .2022 & 1.079 & $4,033 \%$ \\
IBH 26 & 15.3 .2026 & 2.265 & $4,015 \%$ \\
IBH 37 & 15.12 .2037 & 6.558 & $3,948 \%$ \\
IBH 41 & 15.3 .2041 & 7.744 & $3,929 \%$ \\
HFF 24 & 15.2 .2024 & 1.506 & $4,026 \%$ \\
HFF 34 & 15.4 .2034 & 5.218 & $3,969 \%$ \\
HFF 44 & 15.6 .2044 & 8.932 & $3,911 \%$ \\
\hline
\end{tabular}

\section{4 Ávöxtunarkrafa hvers skuldabréfaflokks}

Til að finna ávöxtunarkröfu hvers flokks skyldi bæta skiptiálagi hvers flokks við viðmiðunarkröfuna. Í töflu 5 eru tekin saman viðmiðunarkrafa, skiptiálag og ávöxtunarkrafa hvers flokks.

Tafla 5. Ávöxtunarkrafa hvers skuldabréfaflokks skv. aðferðafræði Íbúðalánasjóðs.

\begin{tabular}{l|ccc}
\multicolumn{4}{c}{ Heimild: Íbuðalánasjóður (2004c) og eigin útreikningar. } \\
\hline Flokkur & $\begin{array}{c}\text { Viðmiðunar- } \\
\text { krafa }\end{array}$ & $\begin{array}{c}\text { Skiptiálag } \\
(\boldsymbol{b} \boldsymbol{p})\end{array}$ & $\begin{array}{c}\text { Ávöxtunar- } \\
\boldsymbol{k r a f a}\end{array}$ \\
\hline IBN 20 & $4,050 \%$ & 0 & $4,050 \%$ \\
IBN 38 & $3,947 \%$ & 0 & $3,947 \%$ \\
IBH 21 & $4,044 \%$ & 21 & $4,254 \%$ \\
IBH 22 & $4,033 \%$ & 21 & $4,243 \%$ \\
IBH 26 & $4,015 \%$ & 21 & $4,225 \%$ \\
IBH 37 & $3,948 \%$ & 22 & $4,168 \%$ \\
IBH 41 & $3,929 \%$ & 24 & $4,169 \%$ \\
HFF 24 & $4,026 \%$ & -2 & $4,006 \%$ \\
HFF 34 & $3,969 \%$ & -2 & $3,949 \%$ \\
HFF 44 & $3,911 \%$ & -2 & $3,891 \%$ \\
\hline
\end{tabular}


Mynd 1 sýnir petta með myndrænum hætti. Á myndinni sést vel hvernig Íbúðalánasjóður hugsaði sér kjörin í skiptiútboðinu. Ávöxtunarkrafa nýju íbúðabréfanna (HFF) liggur á línu sem er tveimur punktum (2bp) fyrir neðan línuna gegnum ávöxtunarkröfu húsnæðisbréfanna tveggja (IBN) og húsbréfin (IBH) liggja 21 - 24 bp fyrir ofan sömu línu.

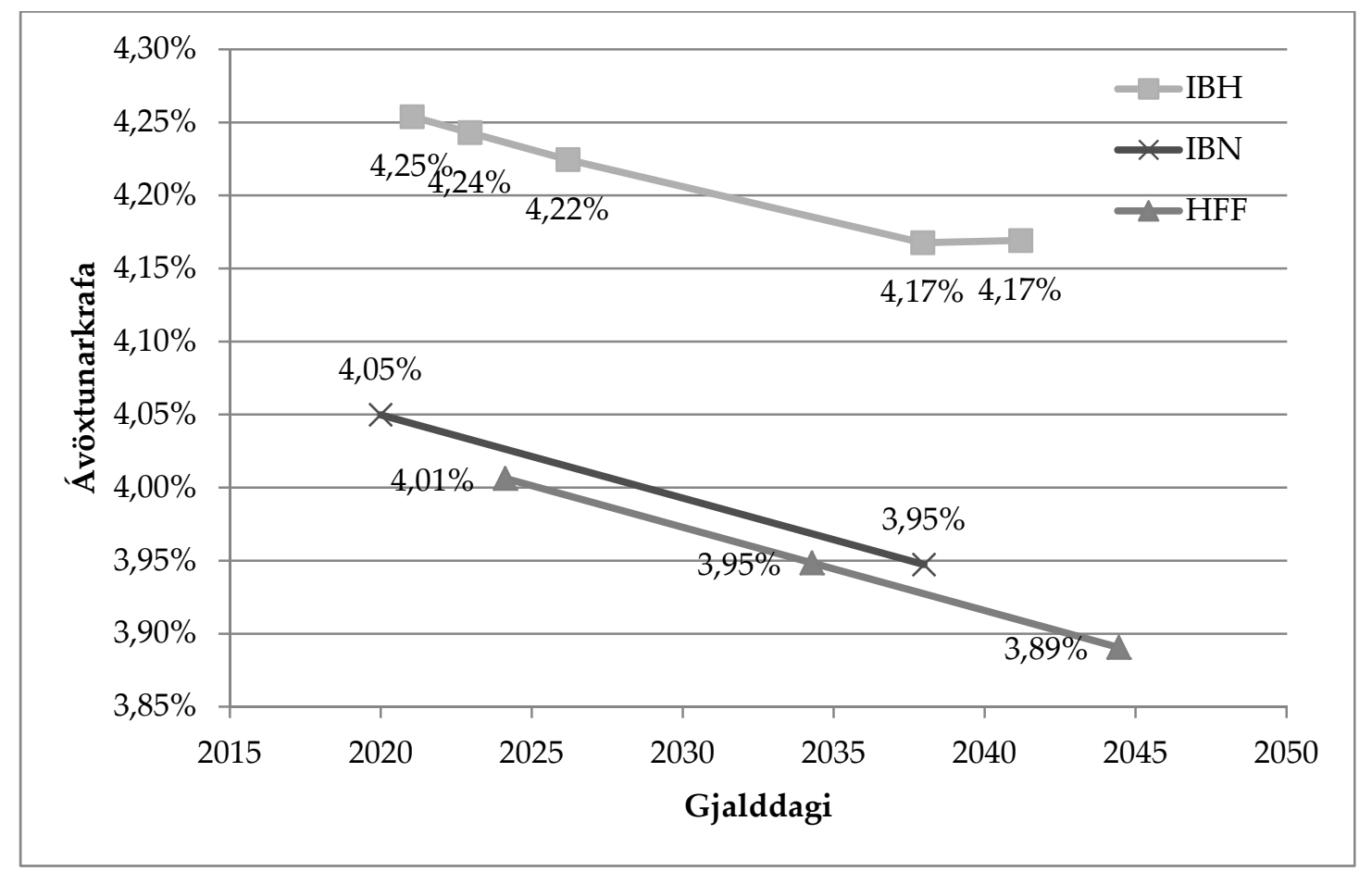

Mynd 1. Reiknuð avöxtunarkrafa í skiptiútboði skv. aðferðafræði Íbúðalánasjóðs. Heimild: Íbúðalánasjóður (2004c) og eigin útreikningar.

\subsection{Skiptaverðið}

Til að ljúka útreikningi á skiptaverði skuldabréfanna í skiptiútboðinu parf aðeins að reikna verð hvers flokks frá ávöxtunarkröfunni sem reiknuð var hér að framan, með pví að nota jöfnur (2), (3) og (7). Niðurstaða pess útreiknings er sýnd í töflu 6 ásamt skiptaverðinu sem Íbúðalánasjóður bauð. Allar forsendur og nákvæmir útreikningar með milliniðurstöðum eru gefnir í töflu 12 í viðauka.

Niðurstaðan er að tilkynnt skiptaverð íbúðabréfanna var of lágt og tilkynnt skiptaverð húsbréfanna var of hátt. Með pví að nota jöfnur (2), (3) og (7) í öfuga átt má reikna út hvaða ávöxtunarkrafa samsvarar tilkynntum skiptaverðum og er niðurstaða pess útreiknings einnig sýnd í töflu 6 (útboðskrafa) sem og hverju munar í ávöxtunarkröfu á hverjum flokki (mismunur). Mynd 2 sýnir myndrænt hvernig raunveruleg ávöxtunarkrafa bréfanna var í útboðinu. Í stað pess að selja íbúðabréfin á lægri kröfu en húsnæðisbréfin seldi Íbúðalánasjóður pau á hærri kröfu. Pá var ávöxtunarkrafa húsbréfanna lægri en Íbúðalánasjóður ætlaði sér. 
Tafla 6. Samanburður á reiknuðu og tilkynntu skiptaverði.

Skiptaverð hvers skuldabréfaflokks reiknað út frá ávöxtunarkröfu skv. aðferðafræði Íbúðalánasjóðs og tilkynnt skiptaverð og samsvarandi ávöxtunarkrafa. Heimild: Íbúðalánasjóður (2004c) og eigin útreikningar.

\begin{tabular}{l|rrrrr}
\hline Flokkur & $\begin{array}{c}\text { Ávöxtunar- } \\
\text { krafa }\end{array}$ & $\begin{array}{c}\text { Rétt } \\
\text { skiptaverð }\end{array}$ & $\begin{array}{c}\text { Tilkynnt } \\
\text { skiptaverð }\end{array}$ & $\begin{array}{c}\text { Útboðs- } \\
\text { krafa }\end{array}$ & $\begin{array}{c}\text { Mismunur } \\
(\boldsymbol{b} \boldsymbol{p})\end{array}$ \\
\hline IBN 20 & $4,050 \%$ & 97,672 & 97,672 & $4,050 \%$ & 0,0 \\
IBN 38 & $3,947 \%$ & 105,487 & 105,487 & $3,947 \%$ & 0,0 \\
IBH 21 & $4,254 \%$ & 207,686 & 207,949 & $4,236 \%$ & $-1,8$ \\
IBH 22 & $4,243 \%$ & 183,034 & 183,275 & $4,226 \%$ & $-1,7$ \\
IBH 26 & $4,225 \%$ & 142,061 & 142,281 & $4,207 \%$ & $-1,7$ \\
IBH 37 & $4,168 \%$ & 189,100 & 189,495 & $4,151 \%$ & $-1,7$ \\
IBH 41 & $4,169 \%$ & 146,373 & 146,681 & $4,154 \%$ & $-1,6$ \\
HFF 24 & $4,006 \%$ & 99,701 & 99,380 & $4,046 \%$ & 3,9 \\
HFF 34 & $3,949 \%$ & 98,992 & 98,548 & $3,987 \%$ & 3,8 \\
HFF 44 & $3,891 \%$ & 98,742 & 98,181 & $3,929 \%$ & 3,9 \\
\hline
\end{tabular}

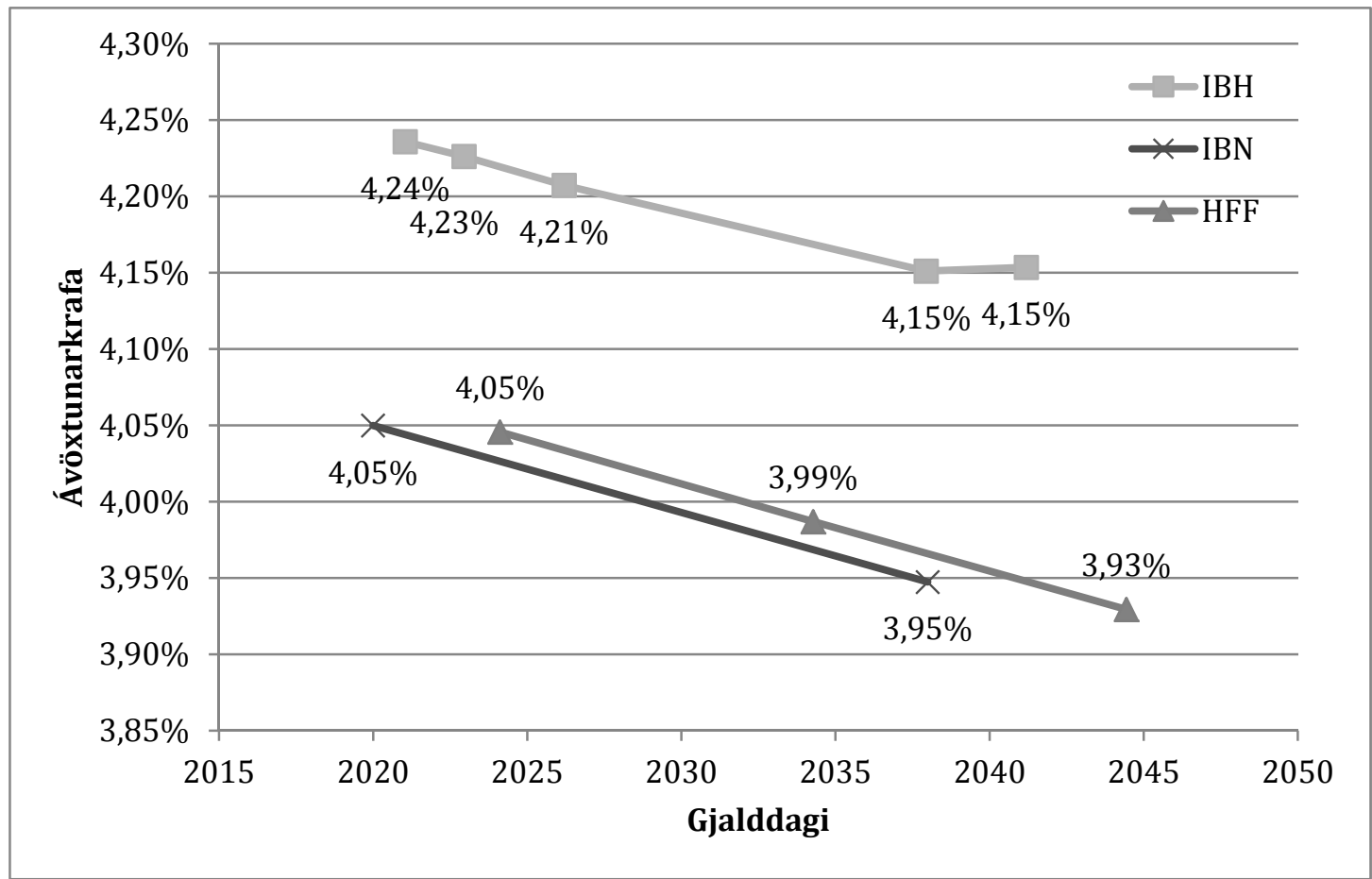

Mynd 2. Raunveruleg ávöxtunarkrafa í skiptiútboði

Heimild: Íbúðalánasjóður (2004f) og eigin útreikningar

\section{$5 \quad$ Mistökin}

Eins og rakið er rækilega og í smáatriðum hér að framan var skiptaverðið sem Íbúðalánasjóður tilkynnti fyrir skiptiútboðið í júní 2004 ekki í samræmi við aðferðina sem lýst er í útboðslýsingunni. Álykta má um hvað fór úrskeiðis með pví að gera breytingar á útreikningunum hér að framan til að fá út sömu skiptaverð og Íbúðalánasjóður tilkynnti um. Ef útreikningunum er breytt á eftirfarandi hátt pá fæst nánast sama skiptaverð og sjóðurinn tilkynnti um: 
1. Í stað dagvísitölunnar fyrir uppgjörsdaginn 7. júlí 2004, $I_{t}=235,85412$, er notuð vísitala júlímánaðar, $I_{t}=235,7$.

2. Fjárhæð útdráttar húsbréfa er reiknuð miðað við að vextir húsbréfanna séu reiknaðir ársfjórðungslega (en ekki árlega eins og raunin er).

3. Ávöxtunarkrafa húsbréfanna er túlkuð sem ársfjórðungsleg ávöxtunarkrafa, p.e. vextir eru reiknaðir fjórum sinnum á ári.

4. Ávöxtunarkrafa íbúðabréfanna er túlkuð sem hálfsársleg ávöxtunarkrafa, p.e. vextir eru reiknaðir tvisvar á ári.

Ef notuð er vísitala júlímánaðar í stað dagvísitölunnar hinn 7. júlí fæst að viðmiðunarkrafa húsnæðisbréfanna er 4,040\% fyrir IBN 20 og 3,942\% fyrir IBN 38 (miðað við árlega vaxtavexti). Ef aðferðinni, sem lýst er í útboðslýsingunni og farið er yfir hér að framan, er svo beitt til að reikna ávöxtunarkröfu hvers bréfs er niðurstaðan eins og sýnd er í öðrum dálki töflu 7. Ef ávöxtunarkrafa húsbréfanna sem pannig fæst er túlkuð sem ársfjórðungsleg ávöxtunarkrafa (sbr. lið 3 að ofan) og íbúðabréfanna sem hálfsársleg ávöxtunarkrafa (sbr. lið 4 að ofan), og fjárhæð útdráttar húsbréfa er að auki rangt reiknuð eins og tilgreint er í lið 2 hér að ofan, pá fást skiptaverðin sem sýnd eru í priðja dálki töflu 7. Í fjórða dálkinum er til hliðsjónar skiptaverðið sem Íbúðalánasjóður bauð í útboðinu. Allar forsendur pessara útreikninga má sjá í töflum 12 og 14 í viðauka.

Tafla 7. Ávöxtunarkrafa og skiptaverð reiknuð miðað við mistök Íbúðalánasjóðs. Ávöxtunarkrafa og reiknað skiptaverð miðað við að gerðar séu fjórar villur í útreikningnum.

\begin{tabular}{l|ccc}
\multicolumn{3}{c}{ Heimild: Íbúđalánasjóður (2004c; 2004f) og eigin útreikningar. } \\
\hline Flokkur & $\begin{array}{c}\text { Ávöxtunar- } \\
\text { krafa }\end{array}$ & $\begin{array}{c}\text { Reiknað } \\
\text { skiptaverð }\end{array}$ & $\begin{array}{c}\text { Tilkynnt } \\
\text { skiptaverð }\end{array}$ \\
\hline IBN 20 & $4,040 \%$ & 97,672 & 97,672 \\
IBN 38 & $3,942 \%$ & 105,487 & 105,487 \\
IBH 21 & $4,245 \%$ & 207,950 & 207,949 \\
IBH 22 & $4,234 \%$ & 183,274 & 183,275 \\
IBH 26 & $4,217 \%$ & 142,280 & 142,281 \\
IBH 37 & $4,163 \%$ & 189,494 & 189,495 \\
IBH 41 & $4,165 \%$ & 146,681 & 146,681 \\
HFF 24 & $3,998 \%$ & 99,379 & 99,380 \\
HFF 34 & $3,942 \%$ & 98,548 & 98,548 \\
HFF 44 & $3,887 \%$ & 98,181 & 98,181 \\
\hline
\end{tabular}

Af töflunni má sjá að skiptaverð reiknað á pennan hátt er nánast pað sama og sjóðurinn bauð í útboðinu. Að hámarki munar 0,001 á verði hvers flokks og pann mun má t.d. útskýra með framsetningu á viðmiðunarverðum húsnæðisbréfanna með premur aukastöfum. Petta er mjög sannfærandi vísbending um að Íbúðalánsjóður hafi einmitt gert pessar fjórar villur við útreikninginn á skiptaverðinu.

Tvær síðustu villurnar snúa að mismunandi framsetningu á ávöxtunarkröfu. Áður en farið er í nánari greiningu á villunum og áhrifum peirra á skiptaverðið og tjón Íbúðalánasjóðs vegna peirra er rétt að fara yfir nákvæmlega hvað mismunandi form vaxta og ávöxtunarkröfu er. 


\section{Mismunandi form vaxta}

Byrjum á einföldu dæmi. Sparifjáreigandi er að íhuga að leggja fé á innlánsreikning í eitt ár hjá öðrum af tveimur bönkum, köllum pá A og B. Innlánsvextir banka A eru 6,1\% en banki B býður $6 \%$ vexti. Banki A reiknar vextina í lok hvers árs og greiðir pá inn á innlánsreikninginn pá. Banki B hins vegar reiknar hlutfallslega vexti og leggur pá inn á reikninginn í lok hvers mánaðar. Séu kr. 100.000 lagðar inná reikning hjá banka A í upphafi árs reiknast vextirnir sem kr. $100.000 \times 6,1 \%$ = kr. 6.100 í lok árs og pví er innstæðan í lok árs kr. 106.100. Hjá banka $\mathrm{B}$ hins vegar reiknast hluti vaxtanna strax í lok fyrsta mánaðar. Í lok mánaðarins leggur bankinn inn kr. $100.000 \times 6 \% / 12=$ kr. 500. Í lok næsta mánaðar reiknast aftur vextir á höfuðstólinn en einnig á vextina sem bættust við höfuðstólinn í lok fyrsta mánaðar og pví bætast við höfuðstólinn kr. $100.500 \times 6 \% / 12$ = kr. 502,50. Svona gengur petta í tólf mánuði og í lok árs er innstæðan á reikningnum í banka B orðin kr. 106.168. Prátt fyrir að banki A bjóði hærri vexti að nafninu til pá greiðir banki B hærri vexti í krónum talið yfir árið. Banki B býður pví í raun hærri vexti.

Ef sparifjáreigandi sem ber saman kjör bankanna horfir eingöngu á vaxtaprósentu hvors banka kemst hann að peirri röngu niðurstöðu að innlánskjör banka A séu betri. Til að bera vextina saman parf hann fyrst að setja pá fram á sama formi, t.d. með pví að reikna virka ársvexti fyrir báða bankana. Virkir ársvextir hjá banka $\mathrm{A}$ eru 6,1\% en hjá banka $\mathrm{B}$ eru peir 6,168\%. Меð samanburði á virkum ársvöxtum er ljóst að kjör banka B eru betri. Samanburður á vöxtum á mismunandi formi er í raun eins og að bera saman tvær vegalengdir par sem önnur er gefin í kílómetrum en hin mílum. Áður en samanburðurinn fer fram parf að setja vegalengdirnar fram í sömu mælieiningu. Reyndar er líklegt að banki B setji líka fram virka ársvexti fyrir innlánsreikning sinn til að leggja áherslu á hvaða pýðingu mánaðarlegur útreikningur vaxta hefur og til að auðvelda viðskiptavinum samanburð við kjör annarra banka.

Í pessu einfalda dæmi eru vextirnir settir fram á mismunandi formi, árlegir vaxtavextir fyrir banka A en mánaðarlegir vaxtavextir fyrir banka B. Fjölmörg önnur vaxtaform eru til, t.d. hálfsárslegir, ársfjórðungslegir og daglegir vaxtavextir, samfelldir vextir og flatir vextir. Öll eru pessi form og fleiri notuð en við mismunandi aðstæður og á mismunandi mörkuðum á sama hátt og fjölmargar mælieiningar eru notaðar fyrir vegalengdir við mismunandi aðstæður og á mismunandi stöðum.

Eins og farið var yfir í kafla 3 er ávöxtunarkrafa skuldabréfs í raun vextir. Fyrir sérhvert form vaxta er pví til samsvarandi form ávöxtunarkröfu. Stærstu mistök Íbúðalánasjóðs við útreikning á skiptaverðinu fólust í að bera saman mismunandi form á ávöxtunarkröfu skuldabréfa án pess að breyta peim fyrst á sama form.

Á íslenskum skuldabréfamarkaði hefur sú venja skapast að ávöxtunarkrafa allra skuldabréfa, par á meðal húsbréfa, húsnæðisbréfa og íbúðabréfa, er gefin upp miðað við árlega vaxtavexti, óháð pví hversu margar afborganir bréfið ber á ári og pví hafa markaðsaðilar ekki purft að huga að pví að setja ávöxtunarkröfu skuldabréfa fram á sama formi.

\section{Villurnar og tjón vegna peirra}

Fjórar villur voru gerðar við útreikning skiptaverðsins í útboðinu. Afleiðing peirra var að verð húsbréfanna, sem Íbúðalánasjóður keypti í útboðinu, var of hátt reiknað og verð íbúðabréfanna, sem sjóðurinn seldi, var of lágt. Sjóðurinn greiddi pví of hátt verð fyrir bréfin 
sem hann keypti og fékk of lágt verð fyrir bréfin sem hann seldi. Рað virðist pví ljóst að Íbúðalánasjóður hafi orðið fyrir tjóni vegna mistakanna. Hér er farið nánar yfir hverja hinna fjögurra villna sem sjóðurinn gerði við útreikning skiptaverðsins og áætlað hversu mikið tjón sjóðsins var vegna hverrar villu.

\subsection{Rangt vísitölugildi}

Fyrsta villan sem tilgreind er hér að framan er að sjóðurinn virðist hafa notast við vísitölu júlímánaðar í stað dagvísitölunnar hinn 7. júlí. Afleiðingar peirrar villu voru hins vegar nánast engar. Par sem sjóðurinn gerði sömu mistökin við útreikning á verðum allra bréfanna hafði pessi villa hverfandi áhrif á endanleg skiptihlutföll í útboðinu. Eina afleiðing villunnar var að ávöxtunarkrafa allra bréfanna í útboðinu hækkaði um 0,5 - 1bp en skiptihlutföllin voru samt nokkurn veginn pau sömu. Ekki er líklegt að pað hafi haft nokkur áhrif á pátttöku í útboðinu og sjóðurinn varð pví líklega ekki fyrir tjóni vegna pessarar villu.

\subsection{Röng fjárhæð útdráttar húsbréfa}

Önnur villan sem tilgreind er hér að framan er að við útreikning á verði húsbréfa miðaði sjóðurinn við að fjárhæð útdráttar húsbréfa væri hærri en hún var í raun. Við útreikning á fjárhæð útdráttarins virðist hafa verið notuð jafnan

$$
C=(1+i)^{t} \frac{i / m}{1-(1+i / m)^{-N}}
$$

par sem $i$ eru ákvæðisvextir húsbréfsins (4,75\%), $t$ er tímalengd (í árum) frá fyrsta vaxtadegi að síðasta gjalddaga, $m$ er fjöldi greiðslna á ári og $N$ er heildarfjöldi greiðslna sem eftir eru, en ekki jafna (7) sem sett var fram í kafla 3.2. Jafna (7) fyrir fjárhæð útdráttar húsbréfa var leidd út frá hinni vel pekktu jöfnu (3) fyrir fjárhæð jafngreiðslu af hefðbundnu jafngreiðslubréfi. Með samanburði á jöfnu (10) við jöfnur (3) og (7) sést að rétt tillit er tekið til eftirstöðva höfuðstóls í jöfnu (10) með pví að margfalda með $(1+i)^{t}$ og nota $N$ í stað $M$. Hins vegar er ekki tekið tillit til pess að ákvæðisvextir húsbréfanna $(i)$ eru settir fram miðað við árlega vaxtavexti en ekki ársfjórðungslega; ákvæðisvöxtunum $i$ er pví stungið beint inn í jöfnu (3) í stað $r$ án pess að leiðrétta pað að um árlega vaxtavexti, en ekki ársfjórðungslega, er að ræða.

Í töflu 8 er sett fram annars vegar rétt fjárhæð næsta útdráttar, reiknuð með jöfnu (7), og hins vegar fjárhæðin reiknuð með jöfnu (10), eins og Íbúðalánasjóður virðist hafa gert. Mismunurinn er á bilinu 0,6\% - 1,1\%. Pessi villa leiðir pví til pess að skiptaverð húsbréfanna var of hátt sem pessu nemur.

Tafla 8. Fjárhæð næsta útdráttar húsbréfa.

Rétt fjárhæð næsta útdráttar húsbréfa (dálkur 2), fjárhæðin sem Íbúðalánasjóður notaði líklega við útreikning skiptaverðsins (dálkur 3) og hlutfallslegur mismunur peirra (dálkur 4). Heimild: Eigin útreikningar.

\begin{tabular}{l|ccc}
\hline Flokkur & $\begin{array}{c}\text { Rétt } \\
\text { fjárhæð }\end{array}$ & $\begin{array}{c}\text { Röng } \\
\text { fjárhæð }\end{array}$ & Mismunur \\
\hline IBH 21 & 3,166859 & 3,186031 & $0,6 \%$ \\
IBH 22 & 2,738164 & 2,756176 & $0,7 \%$ \\
IBH 26 & 2,134996 & 2,151016 & $0,8 \%$ \\
IBH 37 & 2,000381 & 2,021108 & $1,0 \%$ \\
IBH 41 & 1,658150 & 1,676433 & $1,1 \%$ \\
\hline
\end{tabular}


Í útboðinu keypti sjóðurinn húsbréf að verðmæti um 256 milljarðar. Ef verðið sem hann greiddi fyrir var á bilinu 0,6\% - 1,1\% of hátt virðist hægt að áætla að tjón sjóðsins hafi numið á bilinu 1,5-2,8 milljörðum kr. vegna villunnar. Hins vegar eru tvær ástæður fyrir pví að sjóðurinn varð ekki fyrir tjóni vegna pessarar villu. Önnur ástæðan er sú að sjóðurinn gerði aðra villu við útreikning á verði húsbréfanna, sem var að miða við ársfjórðungslega ávöxtunarkröfu, og er skoðuð í næsta undirkafla. Hin ástæðan er að sjóðurinn gerði líklega sömu mistökin tvisvar og seinni mistökin leiðréttu pau fyrri; pessi tvíteknu mistök eru skoðuð gaumgæfilega í undirkafla 7.4.

\section{3 Ársfjórđungsleg ávöxtunarkrafa húsbréfa}

Priðja villa Íbúðalánasjóðs við útreikning skiptaverðsins var að reikna skiptaverð húsbréfanna miðað við ársfjórðungslega ávöxtunarkröfu en ekki árlega. Nánar tiltekið fólst villan í pví að reikna verð húsbréfanna frá ávöxtunarkröfu með eftirfarandi jöfnu, með $m=$ 4, í stað jöfnu (2) í kafla 3.1:

$$
P=\frac{I_{t}}{I_{0}} \cdot \frac{C}{(1+y / m)^{m t_{1}}} \cdot \frac{1-(1+y / m)^{-N}}{1-(1+y / m)^{-1}} .
$$

Með samanburði við jöfnu (2) sést að eini munurinn á pessari jöfnu og jöfnu (2) er að í stað $1+y$ í jöfnu (2) kemur stæðan $(1+y / m)^{m}$ í pessari jöfnu. Рað samsvarar pví að vextir skv. ávöxtunarkröfunni $y$ eru reiknaðir einu sinni á ári í jöfnu (2) en $m$ sinnum á ári í jöfnu (11).

Pessi jafna fyrir verð skuldabréfs út frá ávöxtunarkröfu á uppruna sinn í pví að í stað pess að byggja á jöfnu (1) fyrir núvirði greiðsluflæðis skuldabréfs er notuð eftirfarandi jafna:

$$
P=\frac{I_{t}}{I_{0}} \sum_{i=1}^{N} \frac{C_{i}}{(1+y / m)^{m t_{i}}},
$$

par sem $m$ er fjöldi afborgana af skuldabréfinu á ári. Ef pessi jafna er notuð miðast ávöxtunarkrafan við að vextir séu reiknaðir $m$ sinnum á ári. Eins og fjallað er um hér síðar er pessi jafna notuð víða á skuldabréfamörkuðum til að reikna ávöxtunarkröfu skuldabréfa út frá verði og öfugt og pví er alls ekki sjálfgefið að gerð séu mistök pegar pessi jafna er notuð. Ef hins vegar jafna (11) er notuð fyrir tvö skuldabréf með mismunandi fjölda árlegra afborgana, p.e. mismunandi $m$, og niðurstöðurnar bornar saman, pá er hætta á að mistök eigi sér stað. Gallinn við jöfnur (11) og (12) er nefnilega sá að núvirði nákvæmlega sömu greiðslunnar getur verið mismunandi eftir pví af hvaða skuldabréfi hún er, p.e. eftir pví hve margar greiðslur skuldabréfið ber á ári; jafna (1) er ekki haldin pessum galla. Á meðan borin eru saman bréf með sama fjölda greiðslna á ári veldur petta hins vegar ekki vandræðum.

Pessi villa sjóðsins hafði áhrif á skiptaverð húsbréfanna til lækkunar og jafnaði pví að hluta til út aðra villuna. Í töflu 9 má sjá mismun á rétt reiknuðu skiptaverði og tilkynntu skiptaverði. Endanlegt skiptaverð húsbréfanna var pví aðeins 0,13\% - 0,21\% of hátt vegna pessara tveggja villna. Hins vegar er líklegt að sjóðurinn hafi gert sömu mistök við ákvörðun skiptiálagsins fyrir húsbréfin og ef svo er hefur lokaniðurstaðan verið sú að skiptaverð húsbréfanna var nokkurn veginn rétt reiknað miðað við skiptaverð húsnæðisbréfanna, eins og betur er farið yfir í næsta undirkafla, og tjón sjóðsins vegna pessa pví ekkert. 
Tafla 9. Áhrif annarrar og priðju villu á skiptaverð húsbréfa.

Rétt reiknað skiptaverð húsbréfanna er í öðrum dálki, verðið sem sjóðurinn bauð í útboðinu í priðja dálki, og hlutfallslegur mismunur peirra í fjórða dálki. Heimild: Íbúðalánasjóður (2004f) og eigin útreikningar.

\begin{tabular}{c|ccc}
\hline Flokkur & Rétt verð & Tilkynnt verð & Mismunur \\
\hline IBH 21 & 207,686 & 207,949 & $0,13 \%$ \\
IBH 22 & 183,034 & 183,275 & $0,13 \%$ \\
IBH 26 & 142,061 & 142,281 & $0,15 \%$ \\
IBH 37 & 189,100 & 189,495 & $0,21 \%$ \\
IBH 41 & 146,373 & 146,681 & $0,21 \%$ \\
\hline
\end{tabular}

\subsection{Toítekin mistök}

Hér að framan voru leiddar að pví líkur að Íbúðalánasjóður hafi tvítekið villur 2 og 3, fyrst við ákvörðun skiptiálagsins og svo við útreikning skiptaverðanna út frá ávöxtunarkröfu, og pví hafi lokaniðurstaðan verið sú að skiptaverð húsbréfanna var nokkurn veginn rétt reiknað miðað við skiptaverð húsnæðisbréfanna. Pessu má líkja við að mistök séu gerð í pýðingu íslensks texta yfir á ensku. Ef sami aðilinn pýðir svo aftur enska textann yfir á íslensku, og gerir sömu mistökin, verður niðurstaðan eins og upphaflegi textinn og niðurstaðan pví í raun rétt.

Til nánari útskýringar pá var skiptiálag húsbréfanna á húsnæðisbréfin tilkynnt viku fyrr en endanlegt skiptaverð eða að morgni 21. júní 2004. Skiptiálag húsbréfa var ákvarðað sem mismunur á ávöxtunarkröfu milli húsbréfa og húsnæðisbréfa á markaði í lok dags hinn 18. júní (Sigurður Hallur Stefánsson o.fl., 2014, 2. bindi bls. 75). Hafi sömu mistök verið gerð pegar ávöxtunarkrafa húsbréfanna var reiknuð pá hefur hún verið reiknuð of há og pví skiptiálagið ákvarðað of hátt - um 1,6 - 1,8bp of hátt eins og sjá má í töflu 6. Pegar skiptaverð húsbréfanna var svo reiknað miðað við pað rangt reiknaða álag hefur fengist nokkurn veginn rétt niðurstaða miðað við raunverulegt álag á markaði hinn 18. júní.

Einu áhrifin af pessum tveimur mistökum voru pví líklega sú að skiptiálag húsbréfanna var í raun tæpum 2bp lægra en Íbúðalánasjóður tilkynnti, p.e. um 19bp á stuttu flokkunum premur og 20 - 22bp á lengri flokkunum tveimur. Hugsanlegt er að petta hafi dregið úr áhuga einhverra húsbréfaeigenda á að taka pátt í skiptunum samanborið við pað ef rétt hefði verið greint frá skiptiálaginu, en með hliðsjón af pví hversu mikil pátttakan var í húsbréfaskiptunum er pað pó ekki líklegt.

\subsection{Hálfsársleg ávöxtunarkrafa íbúðabréfa}

Fjórða og síðasta villan sem tilgreind er hér að framan er að sjóðurinn reiknaði skiptaverð íbúðabréfanna miðað við hálfsárslega ávöxtunarkröfu. Nánar tiltekið fólst reiknivillan í að nota sömu jöfnu til að reikna verð íbúðabréfa út frá ávöxtunarkröfu og var ranglega notuð til að reikna verð húsbréfanna, p.e. jöfnu (11). •ó svo að pessi villa hafi verið sambærileg priðju villunni var hún mun afdrifaríkari. Segja má að ástæðan sé sú að pessi mistök gerði sjóðurinn aðeins einu sinni en ekki tvisvar eins og í tilviki húsbréfanna.

Eins og farið er yfir hér að framan er ekki sjálfgefið að mistök séu fólgin í að nota jöfnu (11) til að reikna verð út frá ávöxtunarkröfu eða öfugt. Mistök Íbúðalánasjóðs fólust hins vegar í pví að nota jöfnu (11) fyrir skuldabréf með mismunandi afborganatíðni, annars vegar íbúðabréf með tveimur greiðslum á ári $(m=2)$ og hins vegar húsnæðisbréf með einni greiðslu á ári $(m=1)$ og bera pannig saman ávöxtunarkröfur tveggja skuldabréfa á mismunandi formi, á sama hátt og sparifjáreigandinn í kafla 6 sem eingöngu horfði á vaxtaprósentu bankanna. Eins og fyrr segir hefur skapast sú venja á íslenskum 
skuldabréfamarkaði að ávöxtunarkrafa allra skuldabréfa, par með talið húsbréfa, húsnæðisbréfa og íbúðabréfa, er gefin upp miðað við árlega vaxtavexti, óháð pví hversu margar afborganir bréfið ber á ári og pví hafa markaðsaðilar ekki purft að huga sérstaklega að pví að setja ávöxtunarkröfu mismunandi bréfa fram á sama formi.

Par sem fyrstu prjár villurnar leiddu ekki til verulegs tjóns Íbúðalánasjóðs má meta áhrif fjórðu villunnar með pví að bera niðurstöðu útboðsins saman við pá sviðsmynd að sjóðurinn hefði einungis gert fyrstu prjár villurnar í útreikningi skiptaverðsins; pað einfaldar umfjöllunina og einskorðar hana við pessa einu villu. Pað sem er í pessum undirkafla kallað rétt skiptaverð er pví ekki alveg rétt pví pað miðast við vísitölu júlímánaðar í stað dagvístölu hinn 7. júlí.

Íbúðalánasjóður ætlaði sér að selja íbúðabréfin á lægri ávöxtunarkröfu en húsnæðisbréfin; ávöxtunarkrafa hvers íbúðabréfs átti að vera 2 bp lægri en viðmiðunarkrafan sem reiknuð var með línulegri brúun út frá ávöxtunarkröfu húsnæðisbréfanna. Pannig ætlaði sjóðurinn t.d. að selja íbúðabréfið HFF 24 á ávöxtunarkröfunni 3,998\%. Hann reiknaði hins vegar skiptaverð bréfsins miðað við að ávöxtunarkrafan væri gefin miðað við hálfsárslega vaxtavexti og niðurstaða hans var að skiptaverðið ætti að vera 99,380. Hefði skiptaverðið verið rétt reiknað (pó með vísitölu júlímánaðar) hefði pað verið 99,706. Raunveruleg ávöxtunarkrafa íbúðabréfsins HFF 24 í skiptiútboðinu, miðað við skiptaverðið 99,380, var 4,038\% eða 4bp hærri en ætlunin var og pví 2bp hærri en viðmiðunarkrafan, en ekki 2bp lægri. Í töflu 10 er sýnt rétt skiptaverð (m.v. vísitölu júlímánaðar) fyrir alla prjá flokka íbúðabréfa og til samanburðar skiptaverðið sem Íbúðalánasjóður bauð og raunveruleg ávöxtunarkrafa miðað við pað verð.

Tafla 10. Samanburður á réttu og tilkynntu skiptaverði.

Rétt ávöxtunarkrafa og skiptaverð íbúđabréfa (m.v. vísitölu júlímánaðar) borin saman við tilkynnt skiptaverð íbúðabréfa og samsvarandi ávöxtunarkröfu. Heimild: Íbúðalánasjóður (2004f) og eigin útreikningar.

\begin{tabular}{l|ccccc}
\hline Flokkur & $\begin{array}{c}\text { Ávöxtunar- } \\
\text { krafa }\end{array}$ & $\begin{array}{c}\text { Rétt } \\
\text { skiptaverd }\end{array}$ & $\begin{array}{c}\text { Tilkynnt } \\
\text { skiptaverd }\end{array}$ & $\begin{array}{c}\text { Raunveruleg } \\
\text { krafa }\end{array}$ & $\begin{array}{c}\text { Hlutfallslegur } \\
\text { mismunur }\end{array}$ \\
\hline HFF 24 & $3,998 \%$ & 99,706 & 99,380 & $4,038 \%$ & $0,33 \%$ \\
HFF 34 & $3,942 \%$ & 98,997 & 98,548 & $3,981 \%$ & $0,45 \%$ \\
HFF 44 & $3,887 \%$ & 98,728 & 98,181 & $3,925 \%$ & $0,55 \%$ \\
\hline
\end{tabular}

Pessi villa hafði pví pau áhrif að sjóðurinn seldi íbúðabréfin á of lágu verði sem aftur pýddi að hann purfti að gefa út hærra nafnverð af bréfunum en ella til að greiða fyrir húsbréfin og húsnæðisbréfin. Til að meta tjón sjóðsins af pessari villu nægir að bera saman nafnverð íbúðabréfa sem sjóðurinn gaf út í skiptunum og nafnverð peirra bréfa sem hann hefði gefið út ef rétt hefði verið reiknað (pó m.v. vísitölu júlímánaðar). Pær fjárhæðir eru teknar saman í töflu 11. Niðurstaðan er að sjóðurinn gaf út kr. 1.491.633.413 of mikið að nafnverði af íbúðabréfum. Verðmæti peirra bréfa var um kr. 1.477.845.163. Skuldir sjóðsins eftir skiptin voru pví hærri en ella sem nemur peirri fjárhæð. Tjón sjóðsins vegna villunnar nam pví tæpum 1,5 milljörðum króna. 
Tafla 11. Umframútgáfa íbúðabréfa vegna mistakanna.

Nafnverð útgefinna íbúðabréfa í skiptiútboði (dálkur 2), hversu mikið nafnverð hefði verið gefið út hefði fjórða villan ekki verið gerð (dálkur 3), mismunurinn (dálkur 4) og verðmæti mismunarins (dálkur 5). Heimild: Íbúðalánasjóður (2004e) og eigin útreikningar.

\begin{tabular}{l|rrrr}
\hline Flokkur & Nafnverð skipt & Rétt nafnverð & \multicolumn{1}{c}{ Mismunur } & \multicolumn{1}{c}{ Verðmæti } \\
\hline HFF 24 & 121.756 .093 .423 & 121.357 .998 .158 & 398.095 .265 & 396.924 .865 \\
HFF 34 & 105.893 .953 .621 & 105.413 .672 .550 & 480.281 .071 & 475.463 .852 \\
HFF 44 & 110.686 .736 .197 & 110.073 .479 .120 & 613.257 .077 & 605.456 .447 \\
\hline Alls & $\mathbf{3 3 8 . 3 3 6 . 7 8 3 . 2 4 1}$ & $\mathbf{3 3 6 . 8 4 5 . 1 4 9 . 8 2 8}$ & $\mathbf{1 . 4 9 1 . 6 3 3 . 4 1 3}$ & $\mathbf{1 . 4 7 7 . 8 4 5 . 1 6 3}$ \\
\hline
\end{tabular}

\section{Niðurstaða og umræða}

Niðurstaða greinarinnar er að í skiptiútboði Íbúðalánasjóðs í júní 2004 gerði sjóðurinn fjórar villur í útreikningi á skiptaverðinu. Afdrifaríkasta villan fólst í að verð húsnæðisbréfanna var reiknað frá ávöxtunarkröfu miðað við árlega vaxtavexti (virka ársvexti) en verð íbúðabréfanna var reiknað frá ávöxtunarkröfu miðað við hálfsárslega vaxtavexti (vextir reiknaðir tvisvar á ári) og litið var á ávöxtunarkröfur flokkanna sem sambærilegar. Afleiðing peirrar villu var sú að skuldir Íbúðalánasjóðs urðu tæplega 1,5 milljörðum kr. hærri en ella hefði verið.

Mismunandi form vaxta og meðhöndlun peirra er undirstöðuatriði í fjármálum og yfirleitt með pví fyrsta sem kennt er í grunnnámi í viðskiptafræði. Pví kann mörgum að virðast fráleitt að sérfræðingar í fjármálum hjá alpjóðlegum banka geti gerst sekir um mistök sem má rekja til vanpekkingar á mismunandi vaxtaformum. Ein hugsanleg skýring á pessu er mismunandi venjur við vaxtaútreikning á mismunandi mörkuðum.

Víða á skuldabréfamörkuðum hefur skapast sú venja að ávöxtunarkrafa skuldabréfs er sett fram með vaxtavöxtum sem samsvara afborgunartíðni skuldabréfsins, til dæmis miðað við hálfsárslega vaxtavexti fyrir skuldabréf sem bera tvær afborganir á ári og ársfjórðungslega vaxtavexti fyrir bréf sem bera fjórar afborganir á ári. Рað pýðir að tengsl verðs og ávöxtunarkröfu jafngreiðslubréfa eru gefin með jöfnu (11). Pessi venja hefur ákveðna kosti; til dæmis er verð skuldabréfa pá slétt 100 ef ávöxtunarkrafan er jöfn ákvæðisvöxtum bréfsins, sem á ekki alltaf við um ávöxtunarkröfu sem sett er fram miðað við árlega vaxtavexti. Gallinn við pessa venju er pó sá að pá er útreiknuð ávöxtunarkrafa skuldabréfa með mismunandi afborganatíðni ekki sambærileg, en ef flest bréf á markaðnum hafa sömu afborganatíðni er sá galli lítilvægur. Pessi venja hefur til dæmis skapast á breska ríkisskuldabréfamarkaðnum (United Kingdom Debt Management Office, 2005) par sem langflest skuldabréf bera tvær afborganir á ári. Ráðgjafar Íbúðalánasjóðs voru starfsmenn Deutsche Bank í London og pekktu pví líklega einna best til breska skuldabréfamarkaðarins.

Á íslenska skuldabréfamarkaðnum hefur venjan hins vegar alltaf verið að miða við árlega vaxtavexti fyrir skuldabréf til lengri tíma en eins árs. Einn stærsti kostur peirrar venju er að pá er ávöxtunarkrafa mismunandi bréfa alltaf nokkuð sambærileg; ekki parf að breyta framsetningunni ef bera á saman ávöxtunarkröfu tveggja skuldabréfa með mismunandi afborganatíðni.

Önnur og priðja villan varða húsbréfin. Húsbréfin eru verðtryggð og með útdráttarfyrirkomulagi sem líkir eftir jafngreiðslubréfi. Slík bréf eru ekki vel pekkt alpjóðlega og útreikningur á verði peirra út frá ávöxtunarkröfu eða öfugt er eilítið frábrugðinn samsvarandi útreikningi fyrir hefðbundin jafngreiðslubréf. Pótt flestir íslenskir sérfræðingar í skuldabréfum pekki bréfin og eiginleika peirra nokkuð vel hafa erlendir sérfræðingar oft átt 
erfitt með að átta sig á pessum bréfum. •að parf pví ekki að koma stórkostlega á óvart að ráðgjafar Íbúðalánasjóðs hafi gert mistök við útreikning peirra. Рað var lán í óláni að líklega gerðu peir sömu mistökin tvisvar sem pýddi að sjóðurinn varð ekki fyrir verulegu tjóni vegna peirra.

Póknun Deutsche Bank vegna ráđgjafar við skiptiútboðið nam 10,5 millj. bandaríkjadala eða jafnvirði um 750 millj. kr. á gengi og verðlagi ársins 2004 (Sigurður Hallur Stefánsson o.fl., 2013, 2. bindi bls. 69). Tjón Íbúðalánasjóðs vegna reiknivillunnar nam tvöfaldri peirri fjárhæð á verðlagi sama árs. Misheppnuð ráðgjöf Deutsche Bank kostaði pví sjóðinn 1,5 milljarða kr. auk 750 millj. kr. póknunar og nam heildarkostnaður sjóðsins vegna ráðgjafar Deutsche Bank pví um 2,25 milljörðum kr.

\section{Heimildir}

Bergpóra Bergsdóttir, Ingi Valur Jóhannsson, Sigurður Geirsson, Tómas Örn Kristinsson og Pórður Jónasson. (2003). Endurskipulagning á verðbréfaútgáfu Íbúðalánasjóđs: Álit nefndar um endurskipulagningu á útgáfumálum Íbúðalánasjóðs. Reykjavík: Nefnd um endurskipulagningu á útgáfumálum Íbúðalánasjóðs.

Íbúðalánasjóður. (2004a, 21. júní). Auglýsing vegna skiptiútboðs. Reykjavík: OMX The Nordic Exchange. Sótt 11. apríl 2014 á http://news.icex.is/newsservice/MMIcexNSWeb.dll/ newspage?newsnumber=28752.

Íbúđalánasjóður. (2004b, 11. júní). Breytingar á skuldabréfaútgáfu Íbúðalánasjóðs. Reykjavík: OMX The Nordic Exchange. Sótt 11. apríl 2014 á http://news.icex.is/newsservice/ MMIcexNSWeb.dll/newspage?newsnumber=28699.

Íbúðalánasjóður. (2004c, 28. júní). Exchange offer memorandum dated 28 June 2004. Sótt 11. apríl 2014 á https://www.ils.is/library/Reglur---pdf/ProspectusHFF24_34_44.pdf.

Íbúðalánasjóður. (2004d, 21. júní). Íbúðalánasjóður með tilboð um skuldaskipti í samstarfi við Deutsche Bank. Reykjavík: OMX The Nordic Exchange. Sótt 11. apríl 2014 á http:// news.icex.is/newsservice/MMIcexNSWeb.dll/newspage?newsnumber=28753

Íbúðalánasjóður. (2004e, 2. júlí). Niðurstöður skiptiútboðs Íbúðalánasjóðs. Reykjavík: OMX The Nordic Exchange. Sótt 11. apríl 2014 á http://news.icex.is/newsservice/ MMIcexNSWeb.dll/newspage?newsnumber=28835.

Íbúðalánasjóður. (2004f, 28. júní). Tilkynning skiptaverðs. Reykjavík: OMX The Nordic Exchange. Sótt 11. apríl 2014 á http://news.icex.is/newsservice/MMIcexNSWeb.dll/ newspage?newsnumber $=28796$.

Lög nr. 57/2004 um breytingu á lögum um húsnæðismál, nr. 44/1998, með síðari breytingum.

Seðlabanki Îslands. (2004). Peningamál 19. rit. Reykjavík: Seðlabanki Íslands.

Sigurður B. Stefánsson (ritstj.). (1994). Verðbréf og áhætta. Reykjavík: Verðbréfamarkaður Íslandsbanka.

Sigurður B. Stefánsson (ritstj.). (2003). Hlutabréf og eignastýring. Reykjavík: Íslandsbanki..

Sigurður Hallur Stefánsson, Kirstín P. Flygenring og Jón Porvaldur Heiðarsson. (2013). Skýrsla rannsóknarnefndar Alpingis um Íbúđalánasjóð o.fl. (1.-4. bindi). Reykjavík: Rannsóknarnefnd Alpingis um Íbúðalánasjóð o.fl.

Stjórnskipunar- og eftirlitsnefnd Alpingis. (2014). Álit stjórnskipunar- og eftirlitsnefndar um skýrslu rannsóknarnefndar Alpingis um Íbúðalánasjóð o.fl. 143. löggjafarping. Pingskjal 820 474. mál. 
United Kingdom Debt Management Office. (2005). Formulae for Calculating Gilt Prices from Yields (3. útg.). Sótt 11. apríl 2014 á http://www.londonstockexchange.com/traders-andbrokers/security-types/retail-bonds/dmo-formulae.pdf. 


\section{Viðauki}

Hér eru töflur með forsendum sem liggja til grundvallar öllum útreikningum í greininni.

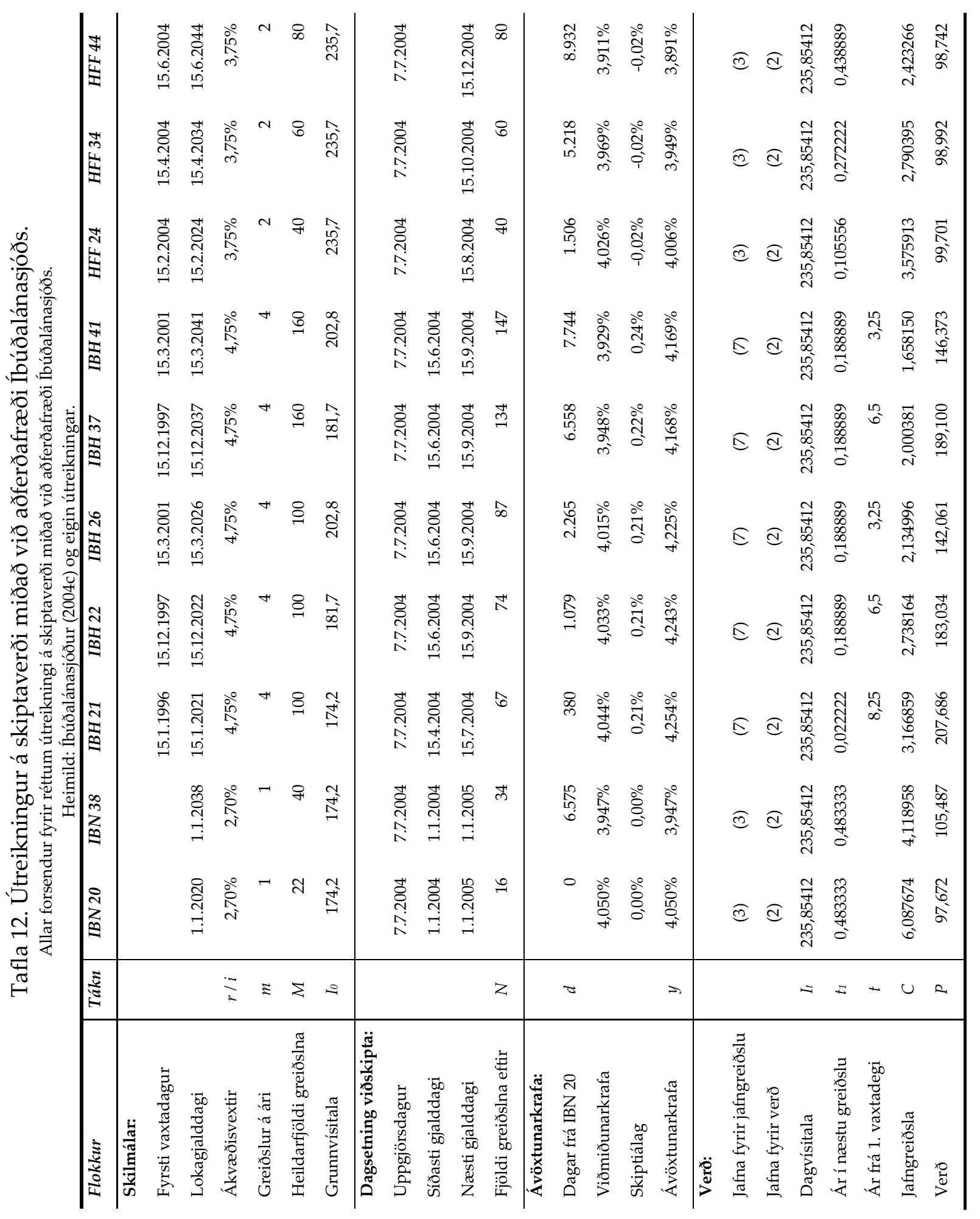



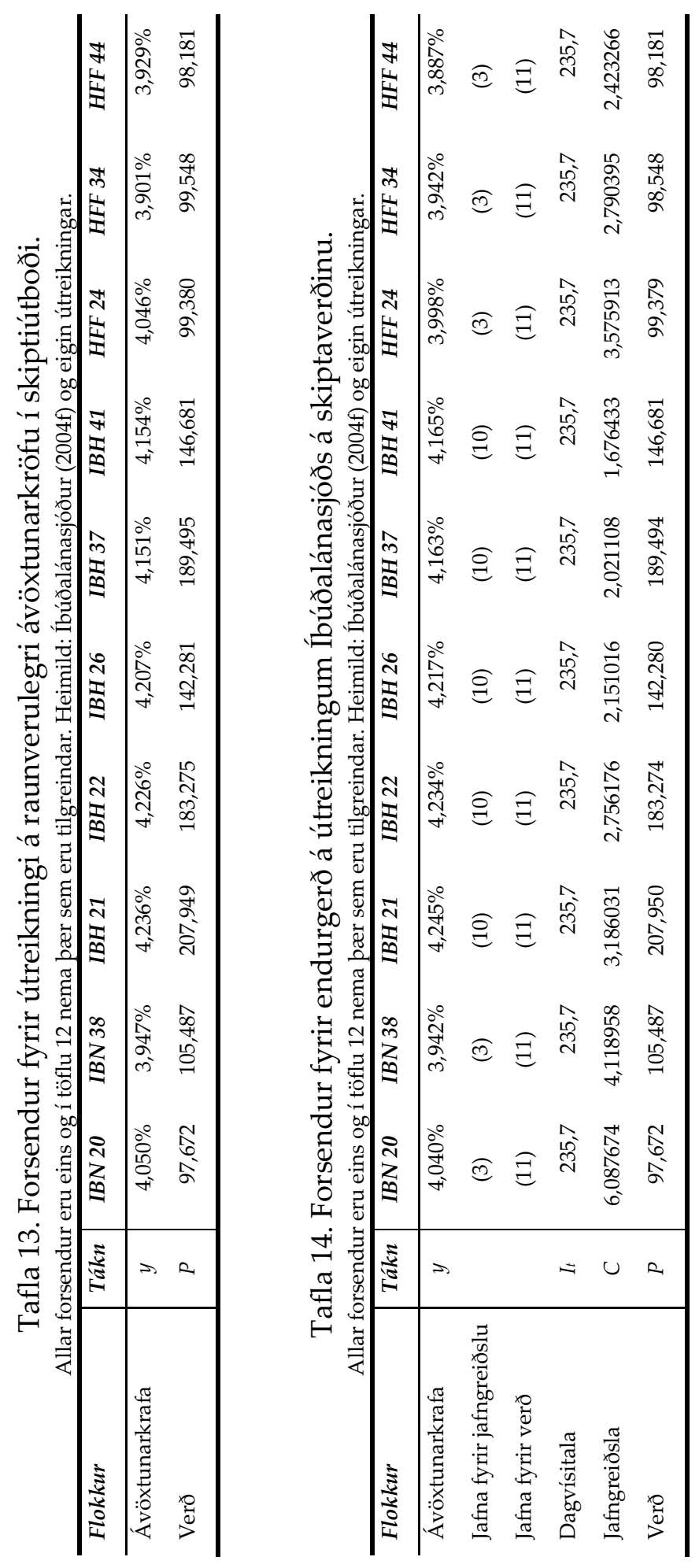